\title{
La radiochimie en amont de la radiobiologie
}

Dans ce numéro, Radioprotection publie un article de J.L. Ravanat intitulé «Les lésions endogènes naturelles et radio-induites de l'ADN : différences et similitudes et implications possibles pour la santé humaine et la radioprotection». Cette revue de littérature de première importance sur la radiochimie des lésions de l'ADN montre leur nature chimique similaire, quel que soit le phénomène induisant cette lésion, radicaux libres oxygénés du métabolisme oxydatif ou rayonnements ionisants. L'auteur analyse de façon approfondie les limites de cette observation, notamment en termes d'effets sanitaires subséquents, et propose quelques perspectives en radioprotection. La radiochimie apparaît ainsi comme une discipline particulièrement importante en amont de la radiobiologie, spécialement aux faibles doses et faibles débits de dose. Quels progrès peut-on attendre? De nouvelles méthodes d'investigation et d'analyse à la fois plus fines et plus globales des différentes lésions de l'ADN permettront-elles un jour de commencer à les différencier selon leur origine ? Pour toutes ces lésions chimiquement similaires de l'ADN, quelle est l'influence de la réponse individuelle en termes de signalisation et de réparation sur les conséquences sanitaires? Les articles traitant de ces questions sont à l'évidence les bienvenus dans le journal Radioprotection.

Nous publions également dans ce numéro un article de C. Mercat et $\mathrm{C}$. Lamouroux intitulé «Évaluation de stratégies de gestion des déchets faiblement radioactifs au regard des critères de la Meilleure Technique Disponible (MTD)». Cet article explore une approche opérationnelle du management des déchets radioactifs en utilisant les douze critères de la méthode MTD proposée par la Directive européenne 96/61EC. Le stockage in situ des déchets radioactifs de faible activité semble meilleur en termes d'efficacité environnementale que la stratégie fondée sur le transfert de cette catégorie de déchets radioactifs vers le site national centralisé de l'Andra. À l'avenir, nous espérons dans notre journal davantage d'articles traitant du sujet des déchets radioactifs.

Aussi dans ce numéro et dans la continuité de notre ligne éditoriale, vous trouverez des articles variés dans tous les domaines de la radioprotection.

Enfin, je voudrais attirer votre attention sur la $2^{\text {nde }}$ édition du livre intitulé «Champs électromagnétiques, environnement et santé » qui vient d'être publié par EDP Sciences en septembre 2018. Cette revue de littérature des connaissances actuelles sur les rayonnements non ionisants (RNI) a été coordonnée par A. Perrin et M. Souques de la section technique RNI de la SFRP. Une note détaillée au sujet de ce livre est consultable à la fin de ce numéro du journal Radioprotection.

\section{Radiochemistry upstream of radiation biology}

In this issue, Radioprotection publishes an article from JL. Ravanat entitled "Endogenous natural and radiation-induced DNA lesions: differences and similarities and possible implications for human health and radiological protection". This review makes the point on the radiochemistry of DNA lesions: it appears that these lesions are similar in their chemical nature whatever the origin of the lesion, natural reactive oxygen species or ionizing radiation (IR). The author analyses in depth the limits of such an observation, notably regarding the subsequent health effects, and proposes some perspectives in radiological protection. Thus, radiochemistry appears as a discipline of paramount importance upstream of radiation biology especially at low doses and low dose rates. Which progress can we expect? Will more precise and more global methods of investigations and analyses of the different DNA lesions allow in the future to begin to differentiate them regarding their origin? For all these chemically similar DNA lesions, what is the influence of the individual response in terms of signaling and repair to the subsequent health effects? Articles dealing with these questions are obviously welcome in Radioprotection.

In this issue, we also publish an article from C. Mercat and C. Lamouroux entitled "Assessment of low radioactive waste management strategies based on the Best REFerence (BREF) criteria". This paper investigates an operational approach for the management of radioactive waste by using the 12 criteria of the BREF method proposed by the European Directive 96/61EC. The in situ storage of low radioactive waste appears better in terms of environmental efficiency than the strategy based on the transfer of this category of radioactive waste to the grouping waste site of Andra. More articles on the issue of radioactive waste are expected in the near future in our journal.

Also in this issue, various articles in the continuity of our editing policy in all domains of radiological protection.

Finally, I would like to draw your attention to the just published 2nd edition of the book entitled "Electromagnetic fields, environment and health" by EDP Sciences in September 2018. This literature review of the current knowledge on non ionizing radiation (NIR) has been coordinated by A. Perrin and M. Souques from the NIR technical section of the SFRP. A detailed note on this book is available at the end of this issue. 